\title{
Algoritma Genetika untuk Mengoptimasi Konsumsi Energi pada Proses Kolom Distilasi Metanol-Air
}

\author{
Totok R. Biyanto \\ Teknik Fisika, Fakultas Teknologi Industri, IT S Surabaya \\ Kampus ITS Keputih Sukolilo Surabaya 60111 \\ Telp : 62315947188 Fax : 62315923626 \\ E-mail: trb@ep.its.ac.id
}

\begin{abstract}
ABSTRAK
Kolom distilasi merupakan unit operasi yang kompleks dan nonlinier. Biaya operasi kolom distilasi yang sangat tinggi menuntut pengembangan metode yang mampu mengoptimasi kosumsi energi. Salah satu altematifmetode tersebut adalah optimasi algoritma genetika. Pemodelan kolom distilasi yang dilakukan menggunakan Jaringan SyarafTinuan(IST) dengan struktur Multi Layer Perceptron (MLP). Struktur input model yang diturunkan adalah struktur Nonlinear Auto Regressive with eXternal input (NARX). Pangaturan bobot bagi jaringan syaraf tiruan dilakukan menggunakan algoritmaLevenbergMarquardt yang mampu memberikan hasil dengan RMSE cukup baik, yakni 3.9974x10 untuk beban energi condenser dan $1.7435 \times 10^{-4}$ untuk beban energi reboiler. Hasil optimasi dengan metode algoritma genetikamendapatkan vaniabel proses pressure top $106.846 \mathrm{Kpa}$, level condenser $30.289 \%$, temperatur feed $83.48{ }^{\circ} \mathrm{C}$, faksi fed 0.5258 , fed $493.518 \mathrm{Kgmol} / \mathrm{jam}$. Hasil optimasi diujikan secara simulasi pada plant hysys dan didapatkan Qc $1.83 \times 10^{7}$ dan Qr 1.33x10 atau menunjukkan terjadinya penurunan beban energi Qc dan Qr, sehingga menghemat biaya steam pada reboiler dan biayacooling water sebesar $46.2 \%$.
\end{abstract}

Kata kunci : Optimasi, Kolom distilasi, Jaringan syaraf tiruan, Algoritma genetika.

\section{ABSTRACT}

Distillation column has multivariable and nonlinear characteristics. High operation cost of distillation column required energy consumption optimization. The new alternative method to find out thelowestenergyconsumtion of distillation column is optimization method using genetic algorithm. In this research, distillation model built up byneural networkMulti Layer Perceptron (MLP) with Nonlinear Auto Regressive with eXternal input (NARX) structure, learning algorithmusing Levenberg-Marquardt. Neural Network model has RMSE 3.9974 $10^{-4}$ for condenser duty and RMSE $1.7435 \times 10^{4}$ for reboiler duty. Genetic algorithm optimization results are Qc 1.85E+07 and Qr 1.05E+07 which process variables are top pressure $106.846 \mathrm{Kpa}$, level condenser $30.289 \%$, temperature feed $83.48{ }^{\circ} \mathrm{C}$, fraction feed 0.5258 , flow feed $493.518 \mathrm{Kgmol} / \mathrm{hour}$. In other word, there are decreasing steam and cooling water cost up to $46.2 \%$.

Keywords: Optimization, Distillation column, Artificial neural network, Genetic algorithm.

\section{PENDAHULUAN}

Metanol akan semakin banyak diperbincangkan dimasa yang akan datang, seiring dengan banyaknya pembuatan energi alternat if terutama dari bio-energi. Produksi metanol adalah salah saturantai dariproses pembuatan energi alternatif, namun keberadaan metanol tidak terlepas dari komponen pengotor misalnya air. Proses pemisahan metanol-air biasanya menggunakan kolom distilasi multitray yangkomplek dan nonlinier.

Distilasi merupakan teknik pemisahan campuran yang terdiri dari dua atau lebih komponen menjadi komponen yang mempunyai tingkat kemurnian

Catatan: Diskusi untuk makalah ini diterima sebelum tanggal 1 Juni 2007. Diskusi y ang layak muat akan diterbitkan pada Jurnal Teknik Elektro volume 7, nom or 1, September 2007. sesuai keinginan. Secara umum teknik distilasi banyak digunakan dalam industri refinery dan industri petrokimia. Permasalahan utama dalam distilasi adalah pemakaian energi yang tinggi [2][6][8].

Beberapa teknik telah dikembangkan untuk mengatasi masalah besarnya komsumsi energi seperti pengintegrasian dari kolom distilasi dengan keseluruhan proses yang secara teori dapat menghasilkan penghematan energi yang signifikan sampai dengan 28-33\% bila dibandingkan dengan konfigurasi konvensional [2]. T eknik lain adalah dengan melakukan optimasi untuk mencari kondisi operasiyang membutuhkan energi yang terkecil. Optimasiini bisa dilakukan dengan memanfaatkan algoritma genetika.

Algoritma genetika adalah algoritma pencarian yang didasarkan pada mekanisme seleksi alamiah dan genetika alamiah. Optimasi algoritma genetika umum 
digunakan karena kemudahan dalam implementasi dan kemampuanya untuk menemukan solusi dengan baik. Penelitian sebelumnya [9], telah menggunakan algoritma genetika untuk optimasi integrasienergi panas pada kolom distilasi agar diperoleh susunan yang paling hemat pemakaian energinya.

Metode algoritma genetika banyak dipakaiuntuk tujuan optimasi numerik dengan merepresentasikan masalah kedalam persamaan matematis. Dengan demikian mutlak diperlukan adanya suatu model untuk merepresentasikan proses kolom distilasi. Namun pengembangan model kolom distilasi yang nonlinear dan multivariabel dengan persamaan matematis menjadi kendala tersendiri berkaitan dengan jumlah persamaan yang dibutuhkan serta waktu penyelesaian yang lama [4].

Menurut [3][4], pemodelan kolom distilasi dapat dilakukan dengan memanfaatkan kelebihan yang dimiliki jaringan syaraf tiruan (JST) dalam membangun hubungan nonlinear antara input-output sehingga memiliki karakteristik yangsama dengan proses yang ditinjau.

\section{Permasalahan}

Permasalahan pada penelitian ini adalah bagaimana membuat model proses kolom distilasi, mengoptimasi beban energi panas reboiler dan condenser pada proses kolom distilasi dengan menggunakan algoritma genetika, dan berapa penghematan biaya karena pengurangan pemakaian energi pada reboiler dan condenser.

\section{Tujuan Penelitian}

Tujuan dari penelitian ini adalah merancang dan menganalisa sistem optimasi pada proses kolom distilasi dengan menggunakan algoritma genetika dalam meminimalkan konsumsi energi ataupenurunan biaya untuk pemakaian steam pada reboiler dan cooling water pada condenser.

\section{TINJAUAN PUSTAKA}

\section{Kolom Distilasi Biner}

Kolom distilasi biner mempunyai kesetimbangan massa [6] dan energi [3][4] yang dapat diterangkan sebagai berikut:

\section{Kese timbangan massa pada kondensor dan reflux} drum

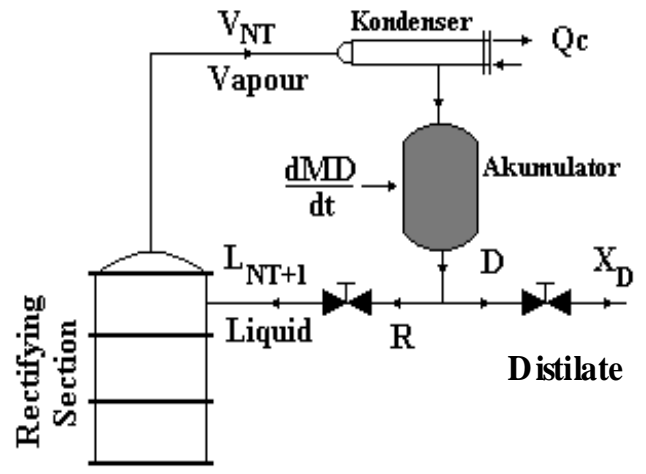

Gambar 1. Kesetimbangan massa pada kondensor dan reflux drum

Neraca massa total:

$\frac{d M_{D}}{d t}=V_{N T}-L_{N T+1}-D$

Neraca massa komponen:

$\frac{d\left(M_{D} X_{D}\right)}{d t}=V_{N T} Y_{N T}-\left(L_{N T+1}+D\right) X_{D}$

Neracapanas:

$\frac{d\left(M_{D} h_{D}\right)}{d t}=V_{N T} H_{N T}-L_{N T+1} h_{N T+1}-D h_{D}-Q c$

\section{Kesetimbangan massa pada tiap tray}

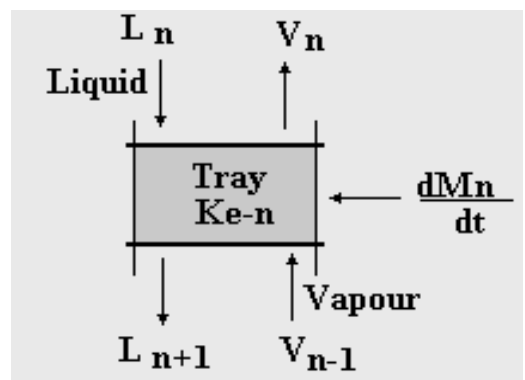

Gambar 2. Kesetimbangan massa pada tiap tray

Neraca massa total:

$\frac{d M_{n}}{d t}=L_{n+1}-L_{n}+V_{n-1}-V_{n}$

Neraca massa komponen:

$\frac{d\left(M_{n} X_{n}\right)}{d t}=L_{n+1} X_{n+1}-L_{n} X_{n}+V_{n-1} Y_{n-1}-V_{n} Y_{n}$

Neraca massa panas :

$\frac{d\left(M_{n} h_{n}\right)}{d t}=L_{n+1} h_{n+1}-L_{n} h_{n}+V_{n-1} H_{n-1}-V_{n} H_{n}$ 
Ke se timban gan massa pada tray umpan $\left(n=N_{F}\right)$

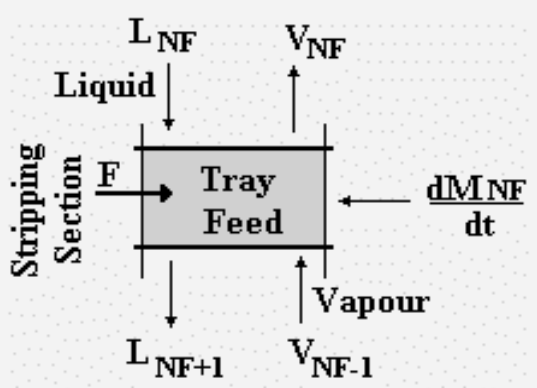

Gambar 3. Kesetimbangan massa pada tray umpan

Neraca massa total:

$\frac{d M_{N F}}{d t}=L_{N F+1}-L_{N F}+F+V_{N F-1}-V_{N F}$

Neraca massa komponen:

$$
\begin{aligned}
\frac{d\left(M_{N F} X_{N F}\right)}{d t}= & L_{N F+1} X_{N F+1}-L_{N F} X_{N F}+ \\
& V_{N F-1} Y_{N F-1}-V_{N F} Y_{N F}+F_{z} X_{F}
\end{aligned}
$$

Neraca panas:

$$
\begin{aligned}
\frac{d\left(M_{N F} h_{N F}\right)}{d t}= & L_{N F+1} h_{N F+1}-L_{N F} h_{N F}+ \\
& V_{N F-1} H_{N F-1}-V_{N F} H_{N F}+F h_{F}
\end{aligned}
$$

Neraca panas:

$$
\frac{d\left(M_{n} h_{n}\right)}{d t}=L_{n+1} h_{n+1}-L_{n} h_{n}+V_{n-1} H_{n-1}-V_{n} H_{n}
$$

\section{Kesetimbangan massa pada reboiler dan base kolom}

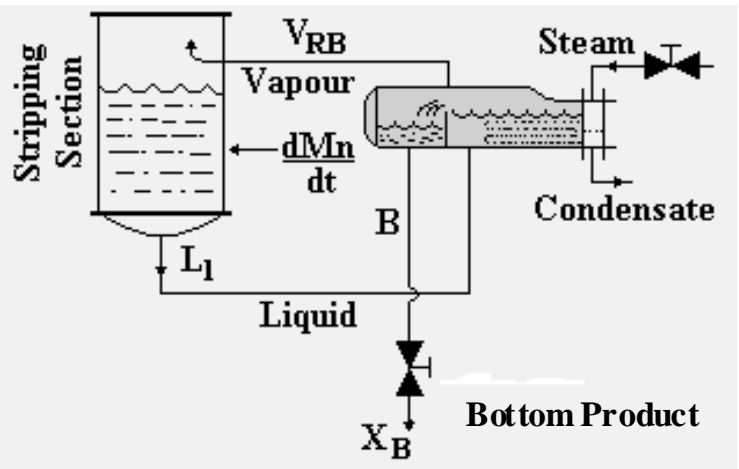

Gambar 4. Kesetimbangan massa pada Reboiler dan base kolom

Neraca massa total:

$\frac{d M_{n}}{d t}=L_{1}-V_{R B}-B$

Neraca massa komponen:

$\frac{d\left(M_{B} X_{B}\right)}{d t}=L_{1} X_{1}-V_{R B} Y_{B}-B X_{B}$
Neraca panas:

$$
\frac{d\left(M_{B} h_{B}\right)}{d t}=L_{1} h_{1}-V_{R B} H_{B}-B h_{B}+Q_{R}
$$

Jaringan Syaraf Tiruan (JST) dengan Algoritma Belajar Levenbeg Marquard

Algoritma Levenberg Marquardt dapat didiringkas sebagai berikut: [7]

1. Pilih vector bobot awal $\mathrm{w}^{(0)}$ dan harga awal $\lambda^{(0)}$.

2. Dimana $w$ adalah bobot dan $\lambda$ diberikan harga awal.

Tentukan arah pencarian.

$\left[R\left(w^{(i)}+\lambda^{(i)} I\right)\right] f^{(i)}=-G\left(w^{(i)}\right)$

diperoleh $\mathrm{f}$ dan dimasukan ke:

$w=\arg \min V_{N}\left(w, Z^{N}\right)$

jika $V_{N}\left(w^{(i)}+\mathrm{f}^{(i)}, Z^{N}\right)<V_{N}\left(w^{(i)}, Z^{N}\right)$ sehingga memenuhi $\mathrm{w}^{(\mathrm{i}+1)}=\mathrm{w}^{(\mathrm{i})}+\mathrm{f}^{(\mathrm{i})}$ sebagai iterasibaru, maka $\lambda^{(\mathrm{i}+1)}=\lambda^{(\mathrm{i})}$. Jika tidak maka mencari harga baru dari $\mathrm{r}$

$r^{(i)}=\frac{V_{N}\left(w^{(i)}, Z^{N}\right)-V_{N}\left(w^{(i)}+f^{(i)}, Z^{N}\right)}{V_{N}\left(w^{(i)}, Z^{N}\right)-L^{(i)}\left(w^{(i)}+f^{(i)}\right)}$

jika $\mathrm{r}^{(\mathrm{i})}>0,75$ maka $\lambda^{(\mathrm{i})}=\lambda^{(\mathrm{i})} / 2$

jika $\mathrm{r}^{(\mathrm{i})}<0,25$ maka $\lambda^{(\mathrm{i})}=2 \lambda^{(\mathrm{i})}$

3. Jika kriteria tercapai, maka perhitungan berhenti. Jika kriteria belum tercapai maka mengulangi langkah nomer 2.

\section{Algoritma Genetika}

Secara umum siklus dari algoritma genetika dapat didefinisikan dalam beberapa langkah sebagaiberikut:

1. Representasi kromosom

2. Penentuan parameter algoritma genetika.

3. Penyusunan populasi awal secara acak.

4. Decoding dari nilai masing-masing kromosom dalam populasi.

5. Perhitungan nilai fitness dari setiap kromosom.

6. Pemilihan kromosom-kromosom untuk membentuk generasi baru.

7. Operasi crossover dan mutasi.

8. Pembentukan populasi untuk generasi berikutnya.

9. Jika prosesnya konvergen ataujumlah generasinya sama dengan batas (input), proses seleksi dan kromosom terbaik sebagai solusi. Jika tidak kembali ke langkah 4

\section{SISTEM YANG DITELITI}

Penelitian ini menggunakan model pemisahan sistem metanol-air dalam kolom distilasi tunggal dengan menggunakan struktur pengendalian L-V. Spesifikasi perancangan sistem ditunjukkan pada Tabel 1 


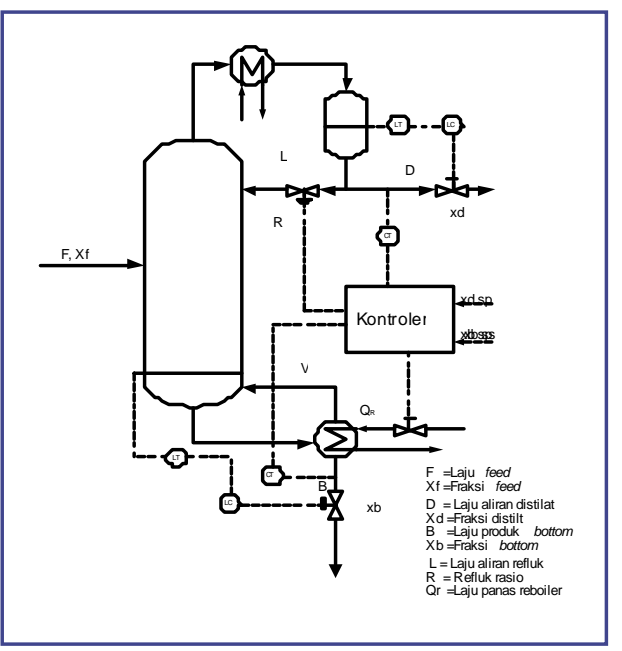

Gambar 5. Struktur kolom distilasi dengan struktur L-V

Tabel 1. Data steady state kolom distilasi metanolair[1]

\begin{tabular}{lr}
\hline Laju feed (F), kgmol/jam & 500,00 \\
Laju distilate (D), kgmol/jam & 250,00 \\
Laju bottom (B), kgmol/jam & 250,00 \\
Komposisi umpan $(X f)$, fraksi mol metanol & 0,5 \\
Komposisi distilate $(X d)$, fraksi mol metanol & 0,99 \\
Komposisi bottom $(X b)$, fraksi mol metanol & 0,01 \\
Perbandingan refluks (reflux ratio) & 1,5 \\
Jumlah tray & 14 \\
Letak tray umpan & 7 \\
Tekanan operasi, atm & 1,0 \\
Beban energi kondensor, $10^{7} \mathrm{~kJ} / \mathrm{jam}$ & 2,189 \\
Beban energi reboiler, $10^{7} \mathrm{~kJ} / \mathrm{jam}$ & 2,122 \\
\hline
\end{tabular}

Kolom tunggal dirancang dengan basis perbandingan refluks sebesar 1,5 kali perbandingan refluksminimum. Sistem yang digunakan adalah metanol-air pada tekanan $1 \mathrm{~atm}$. Kemurnian produk adalah 99\% frsksi mol metanol pada distilat dan $1 \%$ frsksimol metanol pada produk bawah. Konsumsi energipanas untuk reboiler adalah sebesar $2.122 \times 10^{7} \mathrm{~kJ} / \mathrm{jam}$ dan enrgei panas untuk condenser adalah sebesar 2.189 $\mathrm{x} 10^{7} \mathrm{~kJ} / \mathrm{jam}$

Pada penelitian ini, variabel yang dioptimasi (objective function) adalah beban energicondenser (Qc) dan beban energi reboiler (Qr), sedangkan variabel yang dimanipulasi adalah top pressure $(\mathrm{Pt})$, level condenser $(\mathrm{Lc})$, temperatur feed ( $\mathrm{Tf}$ ), fraksifeed (Xf) dan laju feed (F).

\section{PERANC ANGAN}

\section{Struktur dan Training JST}

Pemodelan pada penelitian ini akan menggunakan JST - MLP (Multi Layer Percepton) dengan struktur
NARX (Nonlinear AutoRegressive, eXtemal input) dimana variabel input JST mengandunginput(U) dan output (Y) masa sekarangdan lampau[7]. Persamaan output model $\hat{Y}$ dapat ditulis sebagai berikut:

$\hat{Y}=f\left(Y_{1}, Y_{2}, U_{1}, U_{2}\right)$

dimana:

$\hat{Y}=\left[\hat{y}_{1}(k+1) \hat{y}_{2}(k+1)\right]^{T}$

$\mathrm{Y}_{1}=\left[\mathrm{y}_{1}(\mathrm{k}), \mathrm{y}_{1}(\mathrm{k}-1), \Lambda, \mathrm{y}_{1}\left(\mathrm{k}-\mathrm{ny}_{1}\right)\right]$

$\mathrm{Y}_{2}=\left[\mathrm{y}_{2}(\mathrm{k}), \mathrm{y}_{2}(\mathrm{k}-1), \Lambda, \mathrm{y}_{2}\left(\mathrm{k}-\mathrm{ny}_{2}\right)\right]$

$\mathrm{U}_{1}=\left[\mathrm{u}_{1}(\mathrm{k}), \mathrm{u}_{1}(\mathrm{k}-1), \Lambda, \mathrm{u}_{1}\left(\mathrm{k}-\mathrm{nu}_{1}\right)\right]$

$\mathrm{U}_{2}=\left[\mathrm{u}_{2}(\mathrm{k}), \mathrm{u}_{2}(\mathrm{k}-1), \Lambda, \mathrm{u}_{2}\left(\mathrm{k}-\mathrm{nu}_{2}\right)\right]$

dimana ny dan nu adalah history length untuk output dan input proses.

Menurut [3], pemilihan jumlah layer adalah tiga yaitu layer input, layer hidden dan layer output dengan fungsi aktifasi hyperbolic tangent pada hidden neuron dan fungsi aktifasi linear pada outputneuron, sudah mampu memodelkan sistem dinamik dengan baik. Hal ini sudah dibuktikan untuk memodelkan kolom distilasi menggunakan Matlab dan divalidasi dengan software Hysys [3][4]

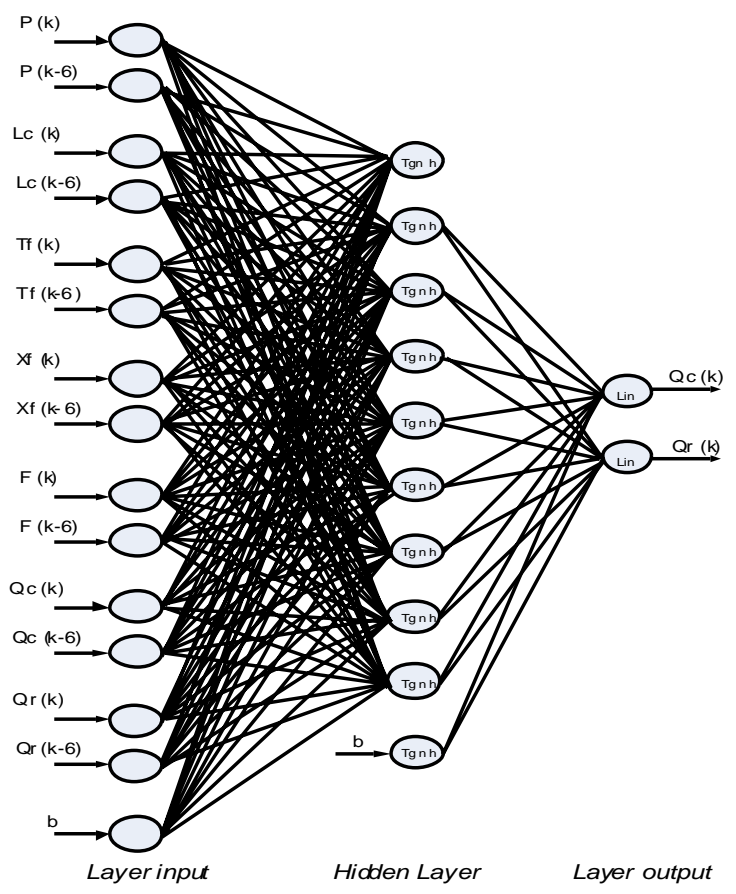

Gambar 6. Struktur model JST

Gambar 6 adalah JST MLP berstrukturinput NARX dengan jumlah layer dan fungsi aktifasi sesuai [7]. Input JST terdiri dari flow feed $(\mathrm{F})$, temperatur feed (Tf), fraksi feed (Xf), pressure top (Pt), level condenser (Lc) serta feed back dari outputyaituQc, Qr pada sampling ke-k sampai sampling kek-6 atau dengan history length 7, sedangkan output JST terdiri dari Qc dan Qr sampling ke-k. Input node terdiri dari 50 node (dit ambah node bias), hidden node terdiri dari 
9 node dan output node terdiriatas 2 node. Sehingga akan menghasilkan matrik $\mathrm{V}=50 \mathrm{x} 9$ yangmerupakan bobot pengali antara layer input dengan layerhidden dan matrik $W=9 \times 2$ yang merupakan bobot pengali antara layer hidden dengan layer output.

Validasi model yang telah dibuat terhadap plant dilakukan dengan memberikan input yang belum pernah dilatihkan kepada JST dan mencatat Root Mean Squared Error (RMSE) yangterjadi sepanjang N sample validasi, seperti Gambar 7. Root Mean Squared Error (RMSE), dapat ditulis sebagaiberikut:

$R M S E=\sqrt{\frac{\sum_{i=1}^{N}\left(y_{i}-\hat{y}_{i}\right)^{2}}{N}}$

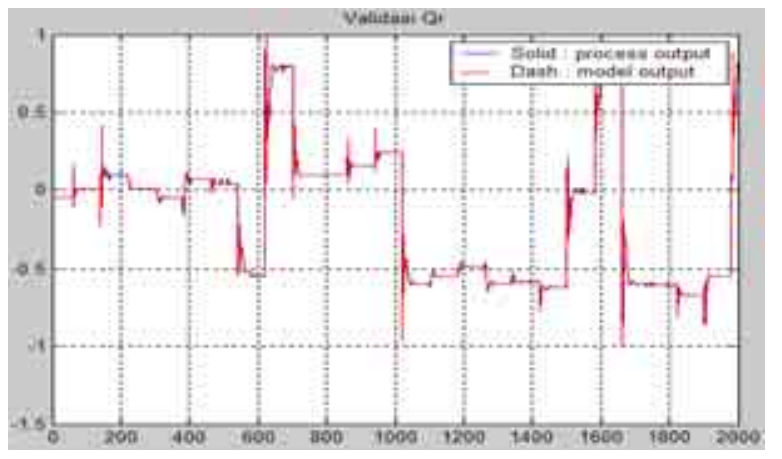

Gambar 7. Validasi output model JST dan outputQr

\section{SIMULASI DAN PEMBAHASAN}

\section{Optimasi Proses kolom distilasi}

Optimasi algoritma genetika dilakukan untuk memperoleh nilai dari variabel proseskolom distilasi yang menghasilkan fitness terbaik, yaitu flow feed $(\mathrm{F})$, temperatur feed ( $\mathrm{Tf}$ ), fraksi feed (Xf),pressure top $(\mathrm{Pt})$, dan level condenser (Lc) sehingga diperoleh beban energi pada condenser dan reboiler yang minimum.

Optimasi algoritma genetika terhadap plant dalam hal ini dilakukan secara offline dengan menggunakan pemodelan JST yang telah melalui prosestraining dan validasi.

Penentuan populasi awal dilakukan secara acak pada range operasi variabel proses kolom distilasi. yai tu pada variabel top pressure $(\mathrm{Pt})$, level condenser $(\mathrm{Lc})$, temperatur feed $(\mathrm{Tf})$, fraksifeed $(\mathrm{Xf})$ dan lajufeed $(\mathrm{F})$. Sedangkan cost function adalah jumlah pemakaian energi condenser $(\mathrm{Qc})$ dan beban energi reboiler $(\mathrm{Qr})$. Optimasi algoritma dilakukan sebanyak tigakali running dengan jumlah generasi 1000 , ukuran populasi 50, probabilitas crossover 0,6 dan probabilitas 0,001 . Grafik kromosom terbaik pada setiap generasi untuk running 1 dapat dilihat pada Cambar 8 Dari Gambar 8 menjelaskan besarnya nilai fitness terbaik untuk tiap generasi. Untuk nunning 1 didapat- kan fitness terbaik pada generasi 302 sebesar 0.065753 . Besarnya nilai fitnessmenandakan fungsi dalam algoritma genetika untuk representasi target yang dinginkan. Dari running 1 didapatkan variabel proses seperti pada Tabel 2

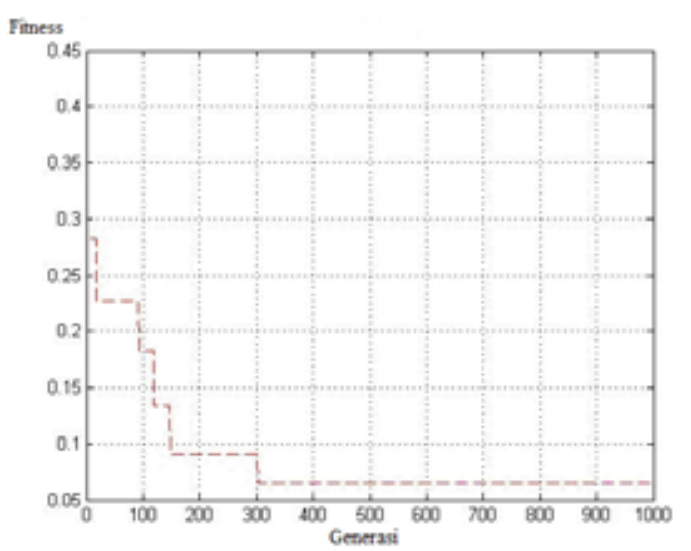

Gambar 8. Fitness algoritma genetika pada running 1

Sedangkan grafik kromosom terbaik pada setiap generasi untuk running ke 2 dan ke 3 dapat dilihat pada Gambar 9 dan 10.

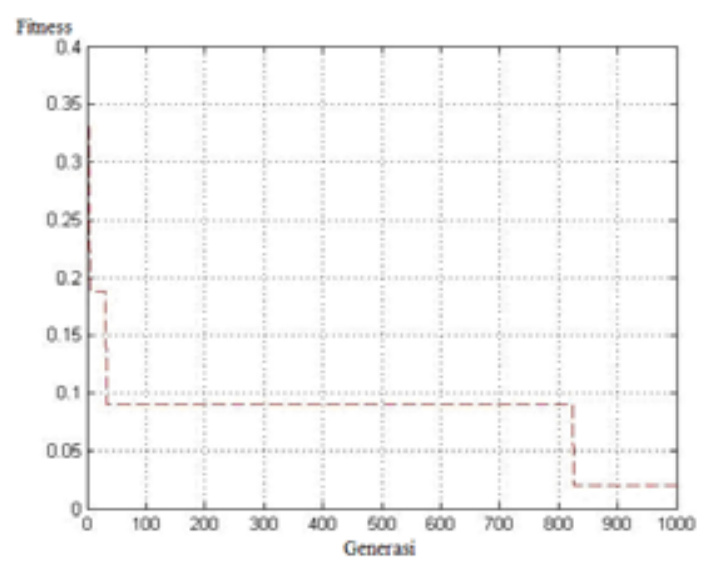

Gambar 9 Fitness algoritma genetika pada running 2

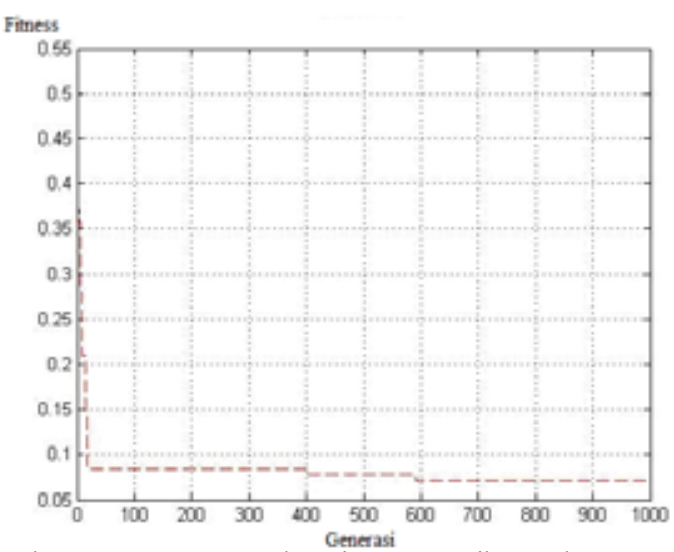

Gambar 10 Fitness algoritma genetika pada running 3

Dari ketiga running diatas didapatkan hasil kromosom yang optimal pada running kedua, hal ini 
ditandai dengan kecilnya nilai fitnessyangditemukan. Sifat pencarian algoritma genetika yang heuristik menyebabkan optimasi bersifat random, sehingga berpengaruh pada proses pencarian fitness yang optimal. Dari proses running sering ditemukan hasil yang berbeda pada tiap running sehingga frekuensi running berdasarkan trial and error sangat mempengaruhi ditemukannya kromosom yang optimal. Hasil dari optimasi algoritma genetika dari ketiga running dapat dilihat pada Tabel 2 .

Tabel 2. Hasil optimasi algoritma genetika

\begin{tabular}{lccc}
\hline & Running 1 & Running 2 & Running3 \\
\hline Pressure & 108.521 & 106.846 & 109.858 \\
Level Condenser & 33.8247 & 30.2894 & 33.716 \\
Temperatur feed & 80.5827 & 83.4816 & 81.7265 \\
Fraksi feed & 0.483821 & 0.525819 & 0.49582 \\
Feed & 508.736 & 493.518 & 508.549 \\
Fitness & 0.065753 & 0.021005 & 0.064977 \\
Generasi & 302 & 825 & 605 \\
\hline
\end{tabular}

\section{Pengujian Hasil Optimasi Algoritma Genetika pada Plant kolom distilasi}

Pengujian hasil dari optimasi algoritma genetika ini dilakukan secara manual dengan memasukan nilai variabel pressure top, level condenser, temperatur feed, fraksi feed dan flow feed dalam simulasiplant kolom distilasi pada software Hysys Variabel proses yang akan dimasukan dalam simulasi plant merupakan variabel hasil optimasi algoritma genetika dengan fitness terbaik. Dari ketiga running algoritma genetika pada Tabel 2 didapatkan kromosom terbaik pada running kedua, hal ini dapat dilihat darinilai fitness yang terbaik yaitu fitness yang paling minimum

Dari hasil running kedua pada Tabel 2 didapatkan variabel dengan fitness terbaik, yaitu pressure top $106.846 \mathrm{kPa}$, level condenser $30.2894 \%$, temperatur feed $83.4816 \mathrm{C}$, Feed $493.518 \mathrm{kgmol} / \mathrm{jam}$, fraksifeed 0.525819 (metanol), dari kelima variabel tersebut kemudian diinputkan pada plant kolom distilasi di software Hysys secara manual.

Dengan memasukan kelima nilai variabel tersebut dalam software Hysys di dapatkan nilai Qc dan Qr sebesar $1.83 \times 10^{7} \mathrm{~kJ} / \mathrm{jam}$ dan $1.33 \times 10^{7} \mathrm{~kJ} / \mathrm{jam}$. Sedangkan nilai Qc dan $\mathrm{Qr}$ sebelum dioptimasi adalah $2.189 \times 10^{7} \mathrm{~kJ} / \mathrm{jam}$ dan $2.122 \times 10^{7} \mathrm{~kJ} / \mathrm{jam}$. Dari hasil pengujian ini menunjukan bahwa optimasi algoritma genetika telah mampumengoptimasiplant dengan ditemukannya nilai dari Pt, Lc, Tf, Xfdan F yang menghasilkan beban energi pada condenser dan reboiler yang minimum. Hal ini dibuktikan dengan nilai Qc dan Qr yang didapatkan dari hasil optimasi algoritma genetika lebih kecil daripada sebelumnya.

\section{Utility Cost}

Perhitungan utility cost dalam penelitian ini dibatasi hanya pada biaya utilitas yaitu biaya steam pada reboiler dan biaya cooling water pada condenser $Q r=2.122 \times 10^{7} \mathrm{kj} / \mathrm{hr}=2.0113 \times 10^{7} \mathrm{BTU} / \mathrm{hr}$

Operating hour $=8000$ hour/year

Dari tabel properties termodinamik steam [5] didapatkan untuk tekanan sebesar 14.69 (lowpressure steam ) $\Delta \mathrm{H}=1151.713-183.3=968.41 \mathrm{BTU} /(\mathrm{lb})(h r)$

$$
\begin{aligned}
\mathrm{m}=\mathrm{Q} / \Delta \mathrm{H}= & 2.0113 \times 10^{7} / 968.41=20768.72 \mathrm{lb} / \mathrm{hr} \\
& =20768.72 \times 8000=1.66 \times 10^{8} \mathrm{lb} / \text { year }
\end{aligned}
$$

Jika ingin mengetahui annual utility cost steam maka hasil diatas dikalikan dengan harga utility cost pada Tabel 3 [8].

Tabel 3. Harga utilitas

\begin{tabular}{lc}
\multicolumn{1}{c}{ Utilitas } & biaya (Januari.1979) \\
\hline Uap: $100 \mathrm{psig}$ & $1.00-2.00 / 1000 \mathrm{lb}$ \\
Air pendingin: & $0.04-0.12 / 1000 \mathrm{gal}$ \\
river or salt & \\
\hline
\end{tabular}

Dengan dasar harga utilitas pada Tabel 3 maka dapat dihitung besar biaya ut ilit asyangharus dibayar seperti yang tercantum dalam Tabel 4.

Harga pada Tabel 4 adalah harga pada bulan Januari 1979. Untuk mengest imasi harga pada tahun ini maka digunakan Marshall dan Swift indeks [8].

$\frac{\text { indeks tahun } 2006}{\text { indeks tahun } 1979} \times$ harga tahun1979= harga tahun 2006

Tabel 4. Biaya utilitas pada Januari 1979

\begin{tabular}{lcc}
\hline \multicolumn{1}{c}{ Keterangan } & sebelum & optimasi \\
\hline Reboiler duty $(\mathrm{kJ} / \mathrm{hr})$ & $2.122 \times 10^{7}$ & $1.05 \times 10^{7}$ \\
Condenser Duty $(\mathrm{kJ} / \mathrm{hr})$ & $2.189 \times 10^{7}$ & $1.85 \times 10^{7}$ \\
Steam Demand(lb/year) & $1.66 \times 10^{8} \mathrm{lb}$ & $8.22 \times 10^{7} \mathrm{lb}$ \\
Cooling Water & $1.71 \times 10^{8} \mathrm{lb}$ & $1.448 \times 10^{8} \mathrm{lb}$ \\
Demand(lb/year $)$ & $2.49 \times 10^{5}$ & $1.23 \times 10^{5}$ \\
Steam Cost $(\$ / \text { year })^{*}$ & $6.84 \times 10^{3}$ & $5.79 \times 10^{3}$ \\
\hline Cooling WaterCost(\$/year)* &
\end{tabular}

Tabel 5. Harga steam dan cooling watertahun 2006

\begin{tabular}{lcc}
\hline & Sebelum optimasi & Sesudahoptimasi \\
\hline Steam Cost(\$/year) & $1.49 \times 10^{6}$ & $7.4 \times 10^{5}$ \\
Cooling Water & $8.08 \times 10^{5}$ & $3.48 \times 10^{4}$ \\
Cost $(\$ /$ year $)$ & \\
\hline
\end{tabular}

Dari Tabel 5 dapat diketahui bahwa optimasi algoritma genetika dapat menghemat biaya operasi pada condenser dan reboiler sebesar $46.2 \%$ pertahun. 


\section{KESIMPULAN}

- Pemodelan kolom distilasi yang nonlineardan kompleks dengan JST berstruktur NARX dan menggunakan algoritma belajar Levenberg-Marquardt dengan RMSE pemodelan terbaik diperoleh sebesar 3.9974 x $10^{4}$ untuk Qc dan 1.7435 x $10^{-4}$ untuk Qr.

- Dari hasil optimasi algoritma genetikapada proses kolom distilasi, menghasilkan nilai Qc sebesar $1.83 \times 10^{7} \mathrm{~kJ} / \mathrm{jam}$ dan Qr sebesar $1.33 \times 10^{7} \mathrm{~kJ} /$ jam dengan nilai variabel proses berupa pressure $106.846 \mathrm{kPa}$, level condenser $30.289 \%$, temperatur feed $83.48{ }^{\circ} \mathrm{C}$, Xf 0.5258 , flow feed $493.518 \mathrm{kgmol} / \mathrm{hr}$.

- Berdasarkan analisa utility cost, optimasialgoritma genetika memberikan penghematan sebesar $46.2 \%$.

\section{DAFTAR PUSTAKA}

[1] Biyanto, TR., "LV, DV and RR-V Binary Distillation Column Control Performance Evaluation", Industrial Electronic SeminarV 2005, Electronic Engineering Polytechnic Institute of Surabaya - ITS, Surabaya, November $24^{\text {th }}, 2005$

[2] Biyanto, TR., Kusmartono, B, Mahfud, AH., "Controllability and Total Annual Cost Analysis of Design and Control Acetone-Ethanol-Butanol Distillation Column with Heat Integration" Journal Academia ISTA Vol.10 No 1, June 2005.

[3] Biyanto, TR., Handogo, R., Suhartanto, T., "Modeling a binary distillation column usinga Neural Network", Chemical Technology for Indonesian Natural ResourcesProcessSeminar, Yogyakarta UPN Veteran University, Yogyakarta, 2004.

[4] Biyanto, TR., Santosa, HH, "Modeling of methanol-water binary distillation column usinga Neural Network", Journal Instrumentasi Vol28 No1, Instrumentation Society of Indonesia, Jakarta. Januari -June 2004,

[5] Geankoplis, Christie J., TransportProcessand Unit Operation, Prentice Hall, India, 1997

[6] Luyben M, Luyben W, Essential of Process Control, McGraw-Hill Chemical Engineering Series. 1997

[7] Norgaard, M., Ravn, O., Paulsen, N.K., Hansen, L.K., Neural Network for Modelling and Control Dynamic Systems, Springer, 2000.

[8] Peters, Timmerhaus, Plant Design and Economics for Chemical Engineers", McGraw-Hill Book Company.New York.1996
[9] Wang, Kefeng, Qian,Yu, "Synthesis and Optimization of Heat Integrated Distillation System using Improved Genetic Algorithm", Chemical Engineering Research Center, South China University of technology, Guanghou, China, 1997. 